\title{
On the Origin of Philippine Vowel Grades
}

\author{
Lawrence A. Reid \\ UNIVERSITY OF HAWAI'I
}

\begin{abstract}
The concept of vowel grade by which morphological features in some IndoEuropean languages are signaled by change in the quality of the vowel of a given form has long been recognized. More recently, the term has also been applied to the variation in vowels that occur in some case-marking prepositional forms in Austronesian languages. The purpose of this paper is to demonstrate some of the processes by which vowel grades developed in some Philippine languages. These processes include what has been referred to elsewhere as vowel-grade harmony, an assimilatory process by which the vowel of one case-marking preposition copies that of another. Noun phrases in many Philippine languages are commonly described as being introduced by "phrase markers" that specify certain syntactic and semantic features of the noun phrase they introduce. These are typically unstressed clitic forms having a CV or CVC shape. However, the quality of the vowel varies from language to language. Thus, in Ivatan, the forms that introduce common noun phrases all have an $u$ vowel, while those that introduce personal noun phrases all have an $i$ vowel; in Tagalog the forms that introduce common noun phrases all have an $a$ vowel, while those that introduce personal noun phrases all have an $i$ vowel, like Ivatan. Recognizing that the similarity in vowel quality of "phrase markers" in these languages is commonly the result of vowel-grade harmony and not necessarily the result of regular phonological change provides an explanation for the multiple irregularities that are found in attempting to reconstruct the protoforms of "phrase markers."
\end{abstract}

1. INTRODUCTION. ${ }^{1}$ Attempts at reconstructing the morphosyntax of Proto-Central Cordilleran, Proto-Northern Luzon, and earlier stages of Philippine and Austronesian languages have run into a number of problems, especially in attempting to reconstruct the forms of the so-called "phrase-markers." This term has been commonly used in recent literature on Philippine languages to label the sets of often monosyllabic, typically unstressed clitics that provide either case-marking information for the phrase they introduce, in which case I analyze them as prepositions, or they specify certain features of the following lexical

I. This paper is a revised version of a paper entitled "Vowel-grade harmony in syntactic change" presented at the Center for Research on Language Change Workshop, Conference of the Australian Linguistic Society, University of Queensland, Brisbane, July 8-9, 2006. I wish to thank the participants at the workshop for their comments, and also to express my appreciation to Hsiu-chuan Liao for her careful editing of the paper, and to Malcolm Ross for several substantive recommendations. I take full responsibility for any issues that remain unclear. Some of the ideas developed here were first proposed in Reid (2006). However, the reconstructions made in this paper are somewhat different from those presented there. 
noun, typically marking it as either personal or not, or providing deictic information relative to the speaker, in which case I analyze the forms as nominal specifiers (Reid 2002).

The problems that are encountered in reconstructing these forms have been noted in various publications. In Reid (I978, I979, I98I, 2006) I outlined several of these problems, one of which had to do with identifying the significance of vowel differences in various sets of apparently reconstructible forms, such as *2i, *?a, and *?u; *ni, *na, and $*_{n u}$; and *si, *sa, and *su; and so on. These vowel differences I labeled as VOWEL GRADES, adopting the term commonly used in Indo-European linguistics for vowel alternations of the sort that resulted in the related English verbs sing, sang, sung, and so forth. Various proposals have been made attempting to reconstruct the meaning of the vocalic alternation in the "phrase-markers." Some languages have utilized the difference to a greater or lesser degree to distinguish personal from common nouns; thus, in Ivatan, the forms $? u, n u, s u$, and $d u$ (with $u$-vowels) introduce, respectively, common noun nominative, genitive, oblique, and locative phrases (in addition to other functions), while the forms $2 i, n i$, and $d i$ (with $i$-vowels) introduce, respectively, personal noun nominative, genitive, and locative phrases. ${ }^{2}$

Similarly in Tagalog, ang, $n g$ [nay], and $s a$ (with $a$-vowels) introduce, respectively, common noun nominative, genitive, and locative phrases, while si, ni, and kay (plural $\left.k_{\text {ina }}\right)^{3}$ (with $i$-vowels) introduce personal noun nominative, genitive, and locative phrases. Ross (2002) proposes for Proto-Malayo-Polynesian a distinction between forms having a *a vowel marking present common nouns, forms having a *u vowel marking absent common nouns, and those having a $*$ i vowel marking personal nouns and default common nouns. Following this pattern, Ross reconstructs genitive phrase markers *na 'common (present)', *nu 'common (absent)', and *ni 'personal; common (default)'.

Blust (2005), discussing only genitive forms, rejects Ross's distinction between *na and *nu, and on the basis of similar systems in Amis and some Central Philippine languages reconstructs for PMP (and PAN) *na 'genitive of plural personal nouns', *ni 'genitive of singular personal nouns', and *nu 'genitive of common nouns' ${ }^{4}$

I claim in this paper that the similarity between vowel grades in at least some of the languages being considered is the result of VOWEL-GRADE HARMONY, a useful cover term to characterize the various processes that operate to create vowel sequences that mark the same (or similar) morphological features or "grades," and accounts for the variation that has been proposed for some reconstructed forms. While vowel copying

2. Oblique phrases in Ivatan, as in other Philippine languages are typically indefinite, and do not allow personal noun exponents.

3. Earlier *kayna, still reflected in Tagalog dialects spoken in Western Marinduque (Soberano I980: I84).

4. The need to possibly reconstruct *na with the function given by Blust was first discussed in Reid (I978:42): "In addition to a distinction between the common noun Det[erminer] and personal noun Det[erminer], there are a number of languages [that] distinguish the marker of a singular from the marking of a plural personal noun. ... Most of the languages accomplish this by replacing the singular marker with a form [that] is identical to the third person plural subject pronoun. Some languages, however, such as Tagalog and Romblon, have added a plural morpheme -na to the singular person marker. This is possibly also the origin of Mamanwa $\sin (<*$ sina), as well as the Aborlan Tagbanwa na [that] replaces the singular DET si. The use of $n a$ as a plural morpheme associated with personal markers, although restricted to a few languages in the Meso-Philippine group, may need to be reconstructed for Proto-Philippines, [because] it is also attested outside of the Philippines as a plural Genitive marker in Amis." 
appears to be operating across phrase boundaries in a syntagmatic relationship, some cases have also been identified where the process appears to be operating between sets of unstressed forms in a paradigmatic relationship. Such changes have typically been considered to fall within the category of analogical change.

In section 2 of this paper, I demonstrate vowel-grade harmony in some of the Central Cordilleran languages, a group of some twenty-five fairly closely related languages forming a major subgroup within the Northern Luzon family of languages of the Philippines. (The internal relationships of the main languages of the Central Cordilleran group are shown in figure I.) I deal specifically with the processes that have resulted in identical vowels in a number of the case-marking prepositions that mark oblique and locative forms. In section 3, I discuss the problems that one encounters in attempting to reconstruct the oblique and locative prepositions for Proto-Central Cordilleran, and in section 4 , I account for the developments that have resulted in the forms found today in the daughter languages.

\section{VOWEL-GRADE HARMONY IN CENTRAL CORDILLERAN} LANGUAGES. In table I, I present a small selection of the case-marking forms that mark oblique and locative noun phrases in some varieties of three of the Central Cordilleran languages. It is apparent from these data that while the consonants remain unchanged for each case form, the vowels vary. Because there is no evidence to suggest that each of the "vowel grades" should be reconstructed to the parent language, Proto-Central Cordilleran, an explanation is needed to account for them in terms of local developments. In the sections that follow, I provide a detailed account of the grammatical functions of each of these forms to show that even though different vowels are involved, their functions of oblique and locative in the languages and dialects in which they occur are to all intents and

TABLE 1. SOME CASE-MARKING FORMS IN CENTRAL CORDILLERAN LANGUAGES

$\begin{array}{lll} & \text { OBLIQUE } & \text { LOCATIVE } \\ \text { KALINGA } & \text { Pus } & \text { ?ud } \\ \text { BALANGAO } & \text { Pas } & \text { Pad } \\ \text { KANKANAEY } & \text { ?is } & \text { ?id }\end{array}$

FIGURE 1. THE CENTRAL CORDILLERAN SUBGROUP OF PHILIPPINE LANGUAGES

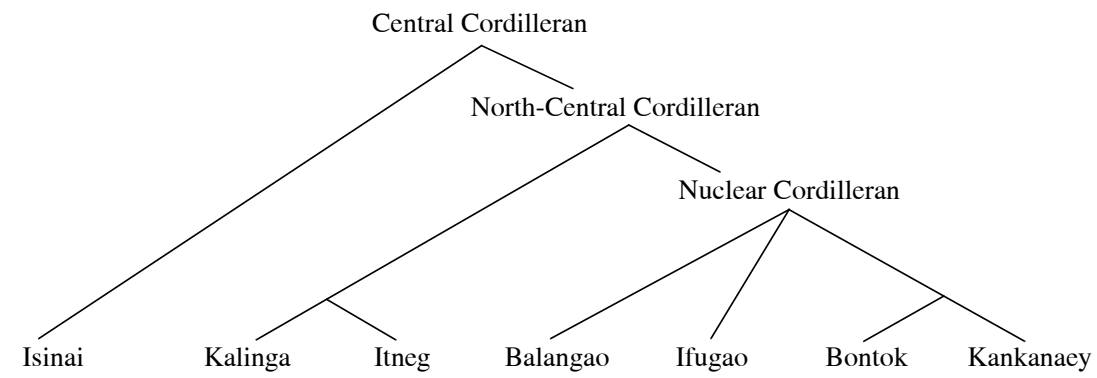


purposes identical. I also show that each of these forms has an alternate consisting of only a single consonant that occurs as an enclitic ( $=s$ 'oblique' and $=d$ 'locative') on preceding vowel-final words, providing a context in which the copying of the vowel in an adjacent phrase may occur. Vowel copying in these cases is arguably the result of analogy, as discussed in section 4, but in other cases one must assume that vowel identity across syntactic boundaries is the result of feature change by which a vowel in one form is completely assimilated to a vowel in a corresponding form.

\subsection{PREPOSITIONS WITH $\boldsymbol{A}$-GRADE IN THE NUCLEAR CORDIL-} LERAN LANGUAGES. Examples of case-marking prepositions and nominal specifiers in three of the Central Cordilleran languages that constitute the Nuclear Cordilleran group are given in $(\mathrm{I}-3) .5$

GUINAANG BONTOK

(I) a. Inmára $=a k$ as fótog ad Fontok ad kasi. got=NOM.IS [ $\left.\mathrm{P}_{\text {овь }} \mathrm{pig}\right]$ [ $\mathrm{P}_{\mathrm{LOC}}$ Bontoc] [ $\mathrm{P}_{\mathrm{LOC}}$ one.day.removed] 'I got a pig in Bontoc the day before yesterday.'

b. As omára $=$ ak as nan fótog as afong=cha as kasi. FUT get $=$ NOM.IS $\left[\mathrm{P}_{\text {овL }} \mathrm{NS} .+\mathrm{DEF}\right.$ pig] [ $\mathrm{P}_{\text {овL }}$ house $\left.=\mathrm{GEN} .3 \mathrm{PL}\right]\left[\mathrm{P}_{\text {овL }}\right.$ one.day.removed] 'I will get some of the pigs from their house the day after tomorrow.'

c. As omára $=$ cha $=\mathbf{s}$ nan áso $=\mathbf{s}$ afong $=$ cha $=\mathbf{s}$ kasi. FUT get $=$ NOM.3PL $=\left[\mathrm{P}_{\text {овL }}\right.$ NS. + DEF dog $]=\left[\mathrm{P}_{\text {овL }}\right.$ house $\left.=\mathrm{GEN} .3 \mathrm{PL}\right]=\left[\mathrm{P}_{\text {овL }}\right.$ one.day.removed $]$ 'They will get some of the dogs from their house the day after tomorrow.'

d. Inára $=\mathbf{n}$ nan laráki san áso=d kasi. $\mathrm{got}=\left[\begin{array}{lll}\mathrm{P}_{\mathrm{GEN}} & \mathrm{NS} .+\mathrm{DEF} & \mathrm{man}\end{array}\right] \quad$ [NS.REC $\left.\mathrm{pig}\right]_{\mathrm{NoM}}=\left[\begin{array}{ll}\mathrm{P}_{\mathrm{LOC}} & \text { one.day.removed }\end{array}\right]$ 'The man got the pig (we were just talking about) the day before yesterday.'

In (Ia), the preposition as identifies the phrase that it introduces as oblique. The common noun fótog 'pig' enables the phrase to be interpreted as an (indefinite) undergoer of the verb. The preposition $a d$ identifies the phrases it introduces as locatives, the first marks a proper-noun spatial location (Fontok is a place name), while the second marks a past temporal location, with kasi 'again' being interpreted as a past-time word, that is, 'one day removed, in the past', or 'the day before yesterday'. In (Ib), the first oblique preposition is separated from the lexical head of the phrase by a nominal specifier nan that marks the following noun as definite, while the second oblique phrase marks a common-noun spatial location, and the third marks a future temporal location, with kasi 'again' being interpreted as a future-time word, that is, 'one day removed, in the future', or 'the day after tomorrow'. Example (Ic) illustrates a common feature of many of the languages of this family. Following vowel-final forms, the prepositions are optionally encliticized to the preceding word, with loss of the vowels of the prepositions.

Guinaang Bontok is an ergative language, so that (Ia), (Ib), and (Ic) are all syntactically intransitive constructions, with the first oblique phrase in each sentence being an "extended" core argument expressing an undergoer (cf. Dixon I994, Dixon and Aikhen-

5. Abbreviations used in this paper that are not included in the Leipzig list are the following: CONJ, conjunction; LG, ligature; NS, nominal specifier; P, preposition; REC, recognitional; RPRT, report; SEQ, sequence. 
vald 2000). Example (Id), however, is a transitive construction. The first phrase after the verb is marked by the enclitic preposition $=n$ as being genitive, expressing the actor. ${ }^{6}$ It is followed by a nominal specifier nan marking the following noun as definite. The next phrase in this example has no case-marking preposition and is nominative. 7 It is introduced by a nominal specifier, in this instance san, marking the following noun as "recognitional," identifying the referent as within the recent common experience of the speaker and addressee. The final phrase illustrates a locative phrase following a vowel-final word, with $a d$ reduced to $=d$.

If we compare the forms of the case-marking prepositions in some of the other Nuclear Cordilleran languages, such as Balangao and Ifugao, we find identical formsapart from the regular sound change $\left(*_{\mathrm{s}}>h\right)$-marking the same functions as are found in Guinaang Bontok, which suggests that reconstruction of the forms to their common protolanguage should not be difficult.

BALANGAO (Shetler I976:233-38)

(2) a. Nampalte=da amin ah babuy ya manù,... kill=[3PL all $]_{\text {Nом }} \quad\left[\mathrm{P}_{\text {овL }}\right.$ pig CONJ chicken $]$

'They all killed pigs and chickens, ...'

b. hen okom=ay mandawéh ah baléy=na... [NS élite $=\mathrm{LG}$ stop.over $\left[\mathrm{P}_{\text {овь }}\right.$ house $\left.\left.=\mathrm{GEN} .3 \mathrm{~s}\right]\right]_{\text {Nом }}$ 'the élite people who stop over at his house ...'

c. Hen andida=y baknang ad Saliyok... [NS those $=\mathrm{LG}$ rich.ones $\left[\mathrm{P}_{\mathrm{LOC}} \text { Saliyok }\right]_{\mathrm{TOP}}$

'As for the rich people at Saliyok ...'

d. Ad namenghan ano, i nanganop ah Amlalawiyén ah pagpag. [ $\mathrm{P}_{\mathrm{LOC}}$ long.ago $\left.\mathrm{RPRT}\right]_{\mathrm{TOP}}$ go hunting [NS Amlalawiyén $]_{\text {Nом }}\left[\mathrm{P}_{\text {овL }}\right.$ forest] 'Long ago, it is said, Amlalawiyén went hunting in the forest.'

e. Yadi hen ap-apo=n hen ongtan. that $\left[\mathrm{NS} \quad \text { lord }=\left[\mathrm{P}_{\mathrm{GEN}} \quad \mathrm{NS} \text { spirit }\right]\right]_{\mathrm{NOM}}$ 'That is the lord of the spirits.'

f. Ibilang=na=h sonod=na ya anà, hen tatagu... count $=[\mathrm{GEN} .3 \mathrm{~S}]=\left[\mathrm{P}_{\text {овL }} \text { sibling }=[\mathrm{GEN} .3 \mathrm{~S}] \text { CONJ children] [NS people }\right]_{\text {Nом }}$ 'He counted the people as his siblings and children ...'

In (2a) the preposition ah case-marks an oblique (indefinite) extended core argument, while in (2b) and (2d) it case-marks an oblique common-noun phrase, expressing a location. In (2c) the preposition $a d$ case-marks a locative proper noun, while in (2d) it case-marks a past temporal location. In (2e) the genitive phrase is case-marked with an enclitic $=n$. Example $(2 \mathrm{f})$ shows that Balangao, like Guinaang Bontok, allows encliticization following vowel-final words, with concomitant vowel deletion.

The Ifugao languages similarly give evidence of inheriting similar forms, as in (3) and (4).

6. The term genitive in this paper is used to label both the actor of a transitive verb, as well as the possessor of a noun, in that the marking of both phrase types is identical in all respects.

7. The term nominative in this paper is used to label the case of the grammatical subject of the sentence, typically labeled absolutive in ergative languages. 
KIANGAN IFUGAO (Lambrecht I978:viii, IO, 3I3, 205, 528)

(3) a. Maíd ah umáli.

NEG.EXIST $[\mathrm{P} \text { come }]_{\text {овL }}$

'No one will come.' Lit. 'None are the ones who will come.'

b. Nalpó=ak ad Bontok ad kabigatán. came $=$ NOM.IS $\left[\mathrm{P}_{\text {LOC }}\right.$ Bontok $] \quad\left[\mathrm{P}_{\text {LOC }}\right.$ morning.time $]$

'I came from Bontok this morning.'

e. ampúyo=n di áki

skirt $=\left[\mathrm{P}_{\mathrm{GEN}} \quad[\mathrm{NS} \quad\right.$ little.girl $\left.]\right]$

'the little girl's skirt'

BATAD IFUGAO (Newell I993: I3, 2 I6, 274, 285)

(4) a. ... umuy $=\mathrm{da}=\mathbf{h}$ wangwang an manālop.

$\mathrm{gO}=[3 \mathrm{PL}]_{\mathrm{NOM}}=\left[\mathrm{P}_{\mathrm{OBL}}\right.$ river $] \quad$ LG fishing

'... they will go to the river to fish.'

b. Hay Hīgib di panayāwan=da=h mā'et.

$[\mathrm{P} \text { Hīgib }]_{\mathrm{PRD}}\left[\mathrm{P}_{\mathrm{NOM}}\right.$ dancing.place $\left.=[3 \mathrm{PL}]_{\mathrm{GEN}}\right]=\left[\mathrm{P}_{\mathrm{OBL}}\right.$ tomorrow $]$

'The place where they will dance tomorrow is Higib.'

The Kiangan Ifugao examples show prepositions marking oblique, locative, and genitive phrases, similar to those in Guinaang Bontok and Balangao. The Batad Ifugao examples in (4) illustrate enclitic oblique prepositions attached to preceding vowelfinal words, as seen also in Guinaang Bontok and Balangao (examples [I] and [2]).

Given the above data, one would be quite justified in reconstructing Proto-Nuclear Cordilleran *?as/=s 'oblique case-marking preposition', *?ad/=d 'locative case-marking preposition', and $*=\mathrm{n}$ 'genitive case-marking preposition' ${ }^{8}$

\subsection{PREPOSITIONS WITH I-GRADE IN THE NUCLEAR CORDIL-}

LERAN LANGUAGES. However, data from other dialects of Bontok and from its closely related sister language, Kankanaey, shown in (5) through (8), suggest that both oblique and locative prepositions had alternate forms with an $i$ vowel.

CENTRAL BONTOK (Benn I99i:I56)

(5) a. Nan innana, esa ay kakhawisan ay ekhad id sangad-om ... [NS innana.ritual $]_{\mathrm{TOP}}$ one LG very.good LG custom [ $\mathrm{P}_{\mathrm{LOC}}$ long.ago]

'The innana ritual, one of the very good customs of long ago ...'

b. Maangnen nan nay innana is nan tinawen ...

done $\quad[\mathrm{NS} \text { this innana.ritual }]_{\mathrm{NOM}}\left[\mathrm{P}_{\text {овц }}\right.$ NS every.year $]$

'This innana ritual is done every year ...'

TOKOKAN BONTOK (Benn I982:5I)

(6) Omchan=kayo akhes is nan afong=yo.

arrive $=$ NOM.2PL also $\quad\left[\mathrm{P}_{\text {овL }}\right.$ NS house $\left.=[\mathrm{GEN} .2 \mathrm{PL}]\right]$

'You (PL) come home to your (PL) house.'

8. Initial glottal stop in these forms is necessary, given the fact that each of the languages is described as having no vowel-initial words. The orthographic practice commonly found throughout the Philippines for the representation of glottal stop is to write such forms as though they were vowel-initial. There is good evidence from prefixation, reduplication, and morphophonemic changes to postulate phonemic glottal stop in initial syllable position for Proto-Central Cordilleran. 
NORTHERN KANKANAEY (Hettick and Kent I967)

Mabalin ay omanay is menkatago=da.

possible LG sufficient [ $\mathrm{P}_{\text {ов }}$ livelihood=[3PL $\left.]_{\mathrm{GEN}}\right]$

'It would be sufficient for their livelihood.'

SOUTHERN KANKANAEY (Allen I978)

(8) Man-abat kanos da gayang en kiling is san sebang di kaong. met RPRT [NS.PL crow with kiling.bird $]_{\text {Nом }}\left[\mathrm{P}_{\text {овL }} \mathrm{NS}\right.$ trail NS Sow]

'The crow and the kiling bird met, it is said, on the trail of a sow.'

\subsection{PREPOSITIONS WITH $A$-GRADE IN THE KALINGA LANGUAGES.}

Looking further afield, to the Kalinga languages that constitute a sister group (with Itneg) of the Nuclear Cordilleran subfamily (see figure I), we note that apparent cognates of the oblique and locative prepositions in Bontok, Kankanaey, and Ifugao are found, some with an $a$ vowel, as in (9-I0), but others with an $u$ vowel, as in (I I-I3).

UPPER TANUDAN KALINGA (Brainard I99I:9, IO, I I, I05)

(9) a. ta in=kayu mangan at=te boroy $=$ ni so.that $\mathrm{gO}=\mathrm{NOM} .2 \mathrm{PL}$ eat $\quad\left[\mathrm{P}_{\mathrm{OBL}}=\mathrm{NS} . \mathrm{S}\right.$ house $\left.=\mathrm{GEN} . \mathrm{IPL} . \mathrm{EXCL}\right]$ 'so that you (PL) go to eat at our (EXCL) house'

b. Sadi kanan da natagu=t=te awe. that say [NS.PL $L_{\mathrm{GEN}}$ lived] $=\left[\mathrm{P}_{\mathrm{OBL}}=\mathrm{NSS}\right.$.S long.ago]

'That is what was said by those who lived long ago.'

c. te bumtak at=te buwang because burst $\quad\left[\mathrm{P}_{\mathrm{OBL}}=\mathrm{NS} . \mathrm{S}\right.$ stomach $]$ 'because it will burst the stomach'

d. Sa kukku gos de ose masapuy=al Lubo. [NS kukku.spirit also] [NS one.LK smoke.out $]_{\mathrm{NoM}}=\left[\mathrm{P}_{\mathrm{LOC}} \mathrm{Lubo}\right]$ 'The kukku is another kind of spirit that can be smoked out in Lubo.'

Upper Tanudan Kalinga has an assimilatory process that affects the final consonant of its case-marking prepositions. Brainard (I99I:I92) notes that the oblique preposition is $a k,{ }^{9}$ where $k$ is the representation of a "fortis glottal stop" that can be replaced by [k]. It assimilates to $p$ before a word whose initial consonant is $b$. This in turn devoices to assimilate to the preceding $p$, so that the sequence ak boroy becomes ap poroy 'to the house'. However, the process seems to be more general than Brainard claims. In (9ac), for example, the oblique preposition is followed by the number-marking nominal specifier $=t e$ 'singular', and in these cases it appears to have assimilated to the initial alveolar consonant of the specifier. That this form was earlier *?as, and has been reanalyzed as $a k$ because of the assimilation process is evidenced from two kinds of data. First, Upper Tanudan Kalinga retains as as the preposition introducing general location exophoric deictics, as sina 'here' and as sidi 'there' (Brainard I99I:I42). ${ }^{10}$ Second, there is a homophonous $a k$ defined by Brainard as the 'nominative singular personal case marker'. This form is the functional equivalent of the ubiquitous $s i$, found throughout other members of the family. In Balangao, however, *si has been replaced

9. Brainard uses the term 'substitute marker'.

Io. Compare Guinaang Bontok as na 'here' and as chi 'there'. 
by $a h(<* *$ ?as) through a process of enclitic homophony discussed in Reid (2006), that also involves vowel-grade harmony. For this form, Brainard (I99I:I92) notes that "the final $k$ frequently assimilates completely to the initial consonant of the following word, as with the person al Laggunawa. $k$ does not assimilate before words beginning with a glottal stop." But if $k$ is the representation of a glottal stop, then one can assume that assimilation is also taking place in this environment. Before words beginning with $s$, then, one can assume that the form of the personal noun marker is $a s$, and that this was its general form, as in Balangao, prior to the introduction of the assimilatory processes. Further evidence will be discussed below that confirms the cognacy of Upper Tanudan Kalinga $a k$ 'oblique preposition' with the Nuclear Cordilleran as forms.

The functions of Upper Tanudan Kalinga $a k$ 'oblique preposition' similarly match those of the Nuclear Cordilleran as forms. In (9a-b), ak introduces phrases that are respectively common noun location and temporal phrases. Although the temporal phrase in (9b) is clearly past, Brainard (I99I:I94) states that "Temporal markers $a k$ and $a d$ occur with time words and time phrases. $A k$ indicates future time, and $a d$ indicates past time." (9b) also indicates that an oblique preposition can lose its vowel and become a clitic to a preceding vowel-final word. (9c) is an example of an oblique preposition introducing a phrase expressing the undergoer of a dyadic intransitive verb. Finally, (9d) shows the locative preposition $a d$, with assimilation to the initial consonant of the following word, introducing a location with a proper place name.

Other Kalinga languages with $a$-grade oblique and locative prepositions are Southern Kalinga (as spoken in Tinglayan, and Mallango), as in (IO).

SOUTHERN KALINGA (Grayden I978: I5, I6)

(Io) a. Nanischung pun ad Pasil...

looked.down when [ $\mathrm{P}_{\mathrm{Loc}}$ Pasil]

'When he looked down on Pasil...'

b. Inagtu=na ta uru=na...

put.on.head=GEN.3S $\left[\mathrm{P}_{\text {овь. }}\right.$ head $\left.=\mathrm{GEN} .3 \mathrm{~S}\right]$

'She put it on her head...'

In (IOa) the locative preposition ad introduces a proper noun locative phrase, while in (Iob) a common noun location is introduced with an oblique preposition $t a$. This is clearly not a formal cognate of the oblique prepositions seen in previous examples, but it does have the expected $a$-vowel. Its source is probably a nominal specifier or a demonstrative that has been reanalyzed as a preposition, following loss of the earlier preposition.

\subsection{PREPOSITIONS WITH $\boldsymbol{U}$-GRADE IN THE KALINGA LANGUAGES.}

Kalinga languages with $u$-grade oblique and locative prepositions include Limos Kalinga, as in (II).

LIMOS KALINGA (Ferreirinho I993:I3, 20)

( I I) a. Ilugan=na sika ut=nat kalitun.

give.ride $=\mathrm{GEN} .3 \mathrm{~S}$ NOM.2S $\left[\mathrm{P}_{\text {овL }}=\mathrm{NS}\right.$ wheelbarrow $]$

'He will give you (SG) a ride in the wheelbarrow.' 
b. Kawad din dalan ud Asibanglan? where [NS path $]_{\text {Nom }}\left[\mathrm{P}_{\text {LOC }}\right.$ Asibanglan]

'Where is the path to Asibanglan?'

c. Mambaat=kami=d Baliwon. travel=NOM.IPL.EXCL=[P $\mathrm{P}_{\mathrm{LOC}}$ Baliwon] 'We (EXCL) are traveling to Baliwon.'

d. 'Ummoy $=\mathrm{da}=\mathbf{d}$ kalabyan. went $=[3 \mathrm{PL}]_{\mathrm{NOM}}=\left[\mathrm{P}_{\mathrm{LOC}}\right.$ yesterday $]$

'They went yesterday.'

In ( I Ia) the oblique preposition that introduces a common noun location is $u t$. The final consonant of this form irregularly replaces $s$, for which there is evidence from Lubuagan Kalinga (as spoken in Balbalasang), as in (I2). The change from earlier *?us to $u t$ was possibly by analogy with the final consonant ending on the Limos Kalinga nominal specifiers, nat and dit, which are themselves combinations of earlier nominal specifiers $n a$ and $d i$, plus an enclitic form of the demonstrative $t u$ or $t a$ (Reid 2006). In ( I I b-c) the locative preposition $u d$ (and its enclitic form $=d$ ) introduce a proper noun location, while in (I Id) the enclitic $=d$ introduces a past temporal location.

\section{BALBALASANG KALINGA (Scheerer I92 I:I89) \\ (I2) ... 'i=na ingīna si lūwang ús=chin phophóyoi ud Photlok.
go $=[\mathrm{GEN} .3 \mathrm{~S}]$ sell $\mathrm{P}_{\mathrm{OBL}}$ water.buffalo $]\left[\mathrm{P}_{\mathrm{OBL}}=\mathrm{NS}\right.$ village $] \quad \mathrm{P}_{\mathrm{LOC}}$ Photlok $]$ \\ '... (which) he went to sell for a water buffalo in the town of Photlok.'}

Lubuagan Kalinga (as spoken in Guinaang), has $o d$ as a locative preposition, as in (I3), but has no oblique preposition with a corresponding vowel.
GUINAANG KALINGA (Gieser I987:5)
(I3) Ammaam =mi imoyon od Guinaang.
take.care $=$ GEN.IPL.EXCL depart $\quad\left[\mathrm{P}_{\text {овL }}\right.$ Guinaang $]$
'We (EXCL) took care in making our departure for Guinaang.'

\subsection{OTHER I-GRADE PREPOSITIONS IN THE CENTRAL CORDIL-} LERAN LANGUAGES. In addition to the forms already discussed, there are two other forms that are reconstructible as oblique and locative prepositions to both ProtoNuclear Cordilleran and Proto-Kalinga-Itneg. They are *si 'oblique preposition' and *di 'locative preposition', reflexes of one or more of which occur both in Nuclear Cordilleran languages, as in (I4-I5), as well as in Kalinga-Itneg languages, as in (I6-I9). A reflex of *si 'oblique preposition' is also found in the Central Cordilleran isolate Isinai (see figure I), as in (20). In languages that allow both glottal stop-initial forms and si forms, as in the Bontok and Kankanaey languages, the distinction between the two is typically stylistic, and does not involve any difference in meaning. Glottal stop-initial forms tend to occur in deliberate speech or following a pause, regardless of whether the final sound of the preceding word is a consonant or a vowel, whereas si forms typically occur only following consonants in the flow of normal conversation. Insufficient data that have both types of preposition are available for the Kalinga languages to determine whether the distinction is stylistic or is determined by some other factor, but 
a comparison of the distribution of the si-forms in the closely related Balbalasang and Guinaang dialects of Lubuagan Kalinga in (I6) and (I7), where one marks an extended core argument of a transitive verb while the other marks common noun locations, suggests that stylistic variation is also involved.

\section{GUINAANG BONTOK}

(I4) Omára=ak si pákhey si árang si kasi.

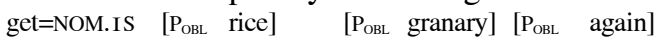

'I will get some unhusked rice from (my) granary the day after tomorrow.'

NORTHERN KANKANAEY (Hettick and Kent I967)

(I5) Dat komaeb si nan kaiw.

then climb [Pовь NS tree]

'Then he climbed into the tree.'

\section{BALBALASANG KALINGA (Scheerer I92 I:I89)}

(i6) ... 'i=na ingīna si lūwang ús=chin phophóyoi ud Photlok. go $=[\mathrm{GEN} .3 \mathrm{~S}]$ sell $\left[\mathrm{P}_{\text {овь }}\right.$ water.buffalo] $\left[\mathrm{P}_{\mathrm{OBL}}=\mathrm{NS}\right.$ village $] \quad\left[\mathrm{P}_{\text {LOC }}\right.$ Photlok $]$

'... (which) he went to sell for a water buffalo in the town of Photlok.'

GUINAANG KALINGA (Gieser I987:9, Io)

(I7) a. Piyaon $=a=n$ manganup si=dat manta'nang on bilig.

like $=[\mathrm{GEN} .3 \mathrm{~S}]=\mathrm{LK}$ hunt $\quad\left[\mathrm{P}_{\mathrm{OBL}}=\mathrm{NS}\right.$ high $\quad$ LK mountain]

'He liked to hunt in the high mountain.'

b. Si Kabunyan, ummillong $\mathbf{s i}=\mathrm{t}$ lamagan od Binalatan.

NS Kabunyan rested $\quad\left[\mathrm{P}_{\mathrm{OBL}}=\mathrm{NS}\right.$ resting.place] [ $\mathrm{P}_{\mathrm{LOC}}$ Binalatan]

'As for Kabunyan, he rested at the resting place on Binalatan.'

Upper Tanudan Kalinga is also reported to have $\sin$ as an oblique form, but no example is provided (Brainard I99I:I94).

BINONGAN ITNEG (Walton I975:22)

( I8) Napan=da di Tomeng-ey inggana di Lowaben, inmangoway.

went $=[3 \mathrm{P}]_{\text {Nом }}\left[\mathrm{P}_{\text {LOC }}\right.$ Tomeng-ey $]$ until $\left[\mathrm{P}_{\mathrm{LOC}}\right.$ Lowaben $]$ go.gather.rattan

'They went to Tomeng-ey as far as Lowaben, gathering rattan.'

LACUB ITNEG (Yamada and Tsuchida I975:53)

(I9) utpám din bułóy si gúłon

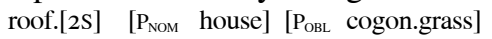

'Thatch the house with cogon grass.'

ISINAI (Reid I973)

(20) Pin?inumar mangia?bu si bavuy?

how catch [Р овь pig]

'How does one catch a pig?' (0007)

3. PROTO-CENTRAL CORDILLERAN RECONSTRUCTIONS. A comparison of all the forms discussed above suggests the possibility of reconstructing a variety of different oblique and locative case-marking forms for Proto-Central Cordilleran. These are shown in table 2. As noted above, the clitic forms attached to vowel-final preceding words, while the free forms typically occurred following consonant-final words. 
Looking first at the locative forms shown in table 2, we note that three different vowels are found, the forms being *?ad, *?id, and *?ud. These, along with the other reconstructible form, *di (originally probably a distal demonstrative in the parent of the Philippine languages), suggest that there may have been a three-way set of locative forms, *?a=di, *?i=di, and *?u=di, that were distinguished by the quality of the vowel at some early point in the history of these languages, corresponding in some way to the set of genitive forms, *na, *ni, and *nu first proposed in Reid (198I), and discussed more recently by Ross (2002) and Blust (2005).

\subsection{ARE VOWEL-GRADE PREPOSITIONS RECONSTRUCTIBLE TO PROTO-CENTRAL CORDILLERAN? There are several problems that arise if} one attempts to reconstruct each of the forms listed in table 2 to Proto-Central Cordilleran. The first is that although there is external evidence in Cordilleran languages for a locative form with an $i$-vowel, for example, in Ilocano idi and idiay occurring in past temporal phrases such as idi kalman 'yesterday' and spatial phrases such as idiay eskuela 'to school' (Rubino 2000:2I4), to my knowledge there is no evidence for the postulated full locative forms *?a=di and *?u=di in any Philippine language.

The second problem is that there is no difference in meaning between the reflexes of *?ad, *?id, and *?ud in the languages that have them. The third problem is that there seems to be no explanation for why even closely related dialects in adjacent communities (such as Guinaang Bontok and Central Bontok) sometimes reflect different forms. Finally, the oblique forms of languages match the vowel-grade of their locative preposition; those with ?ad 'locative' have ?as 'oblique'; those with Rid 'locative' have ?is 'oblique'; and Limos Kalinga with ?ud 'locative' has ?ut (<*?us) 'oblique', suggesting that a vocalic template is applied to the forms.

There is no evidence, moreover, that this template is associated with deictic reference. The forms function only to mark case. Deictic reference is carried by nominal specifiers, or by demonstratives that follow the specifiers. It is possible, then, that only *si and its enclitic form * $*$ s are reconstructible as oblique prepositions, and that only *?i=di and $*=\mathrm{d}$ are reconstructible as locative prepositions to Proto-Central Cordilleran, as proposed in table 3 .

TABLE 2. POSSIBLY RECONSTRUCTIBLE OBLIQUE AND LOCATIVE CASE-MARKING PREPOSITIONS
OBLIQUE
LOCATIVE
$\mathrm{V}] *=\mathrm{s}$
$*=\mathrm{d}$
C] *?as / *?is / *?us / *si
$*$ ?ad / *?id / *?ud / *di

TABLE 3. PROPOSED PROTO-CENTRAL CORDILLERAN OBLIQUE AND LOCATIVE CASE-MARKING PREPOSITIONS

$\begin{array}{lll} & \text { Oblique } & \text { Locative } \\ \mathrm{V}] & *=\mathrm{s} & *=\mathrm{d} \\ \mathrm{C}] & * \mathrm{si} & * \mathrm{ri}=\mathrm{di}\end{array}$


4. HOW DID VOWEL GRADES DEVELOP? The beginning assumption is that Proto-Central Cordilleran had only *si oblique and *?i locative prepositions, and that *di was a Proto-North Luzon distal demonstrative that had developed as a nominal specifier long before Proto-Central Cordilleran developed, introducing past-time words, as in Ilocano, and proper noun locations. This latter function of the nominal specifier *di is a feature of a number of Northern Cordilleran languages, and is widespread in scores of northeastern Luzon place names that begin with the form, such as Disulap, Disabungan, Dicatian, Dibol, Divilacan, and so on. By the time Proto-Central Cordilleran developed, both *si and *di would have had (optional) enclitic forms following vowels, resulting in *=s and $*$ ? $=\mathrm{d}$. But $*$ di could also occur independently as a locative preposition, that is, without being encliticized to *?i, and its enclitic form *=d could be attached to vowel-final words in the same way that $*=\mathrm{s}$ could. This created an analogical proportion $[*=\mathrm{d}: *$ id $:: *=\mathrm{s}:$ ?], that resulted in the development of the $i$-grade preposition *?is. These developments are shown in table 4 .

This explanation provides a satisfactory account of the development of the $i$-grade oblique and locative forms, but it does not help in understanding how the $u$-grade forms developed. Data from Southern Cordilleran languages provide a possible clue. Southern Cordilleran is a subgroup of some eight languages that constitutes, together with the Central Cordilleran subgroup, a fairly well-defined branch of the Northern Luzon family, called South-Central Cordilleran. An examination of the locative prepositions in this group enables the reconstruction of Proto-Southern Cordilleran locative forms *di and *=d, functioning in very similar ways to those discussed above for the Central Cordilleran languages. The only glottal-initial locative form is found in Pangasinan. It is ed ([?əd]), from earlier *?ad, as in (2 Ia). The form $d i$ is found only in frozen locative demonstratives, although its enclitic form $=d$ still occurs, as in $(2 \mathrm{Ib})$.

PANGASINAN (Benton I97I:54, 58)

(2 I) a. Manalíw=ka=y kárne ed tindáan.

buy $=[$ NOM.2S $]=[\text { NS meat }]_{\text {овь }}$ [P Loc $_{\text {L }}[$ market $\left.]\right]$

'You (SG) will buy meat in the market.'

b. Nananáp si Linda na manók dimá=d hardín. caught [NS Linda $]_{\text {NOM }}\left[\mathrm{P}_{\mathrm{GEN}}\right.$ [chicken]] there $=\left[\mathrm{P}_{\mathrm{LOC}}\right.$ [garden] $]$

'Linda caught a chicken there in the garden.'

Of interest in this group is the presence of a form $s u$ with a wide range of functions. In some of the languages, such as Pangasinan, it occurs as a preposition introducing nominative phrases, as in (22).

PANGASINAN (Benton I97i:60)

(22) Dapít diyá so abóng=to.

near here $\left[\mathrm{P}_{\mathrm{Nom}}\right.$ house $\left.=\mathrm{GEN} .3 \mathrm{~S}\right]$

'His house is around here.'

TABLE 4. THE DEVELOPMENT OF I-GRADE CASE-MARKING PREPOSITIONS

\begin{tabular}{|l|l|l|}
\hline & OBLIQUE & LOCATIVE \\
\hline $\mathrm{V}]$ & *=s & *=d \\
\hline $\mathrm{C}]$ & *si & (di, *2id \\
\hline
\end{tabular}

\begin{tabular}{|l|l|l|}
\hline & OBLIQUE & LOCATIVE \\
\hline $\mathrm{V}]$ & $*=\mathrm{s}$ & $*=\mathrm{d}$ \\
\hline $\mathrm{C}]$ & $* \mathrm{si}, *$ ?is & $* \mathrm{di}$, *?id \\
\hline
\end{tabular}


In Inibaloi, it also has this function, as in (23a), but it also functions as an oblique pronoun, substituting for any specific oblique noun phrase, as in (23b), and may be followed immediately by a genitive phrase introducing oblique phrases with animate nouns, as in (23c).

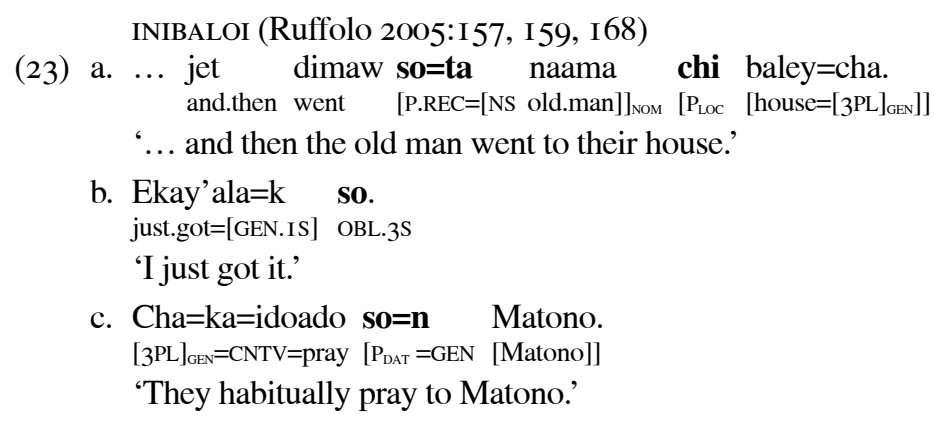

In Karao, so also occurs. Brainard (2003:8) says that "when so is present [in a dependent clause] it is coreferential with the object of the independent counterpart of the dependent clause." In this environment it functions either as an oblique deictic pronoun or, when followed by a noun, as an oblique nominal specifier. ${ }^{I I}$ In other Philippine languages, such as Ivatan (24), and at least two of the Northern Cordilleran languages, Gaddang (25) and Yogad (26), we also find a reflex of *su introducing common noun oblique phrases. ${ }^{\mathrm{I}}{ }^{2}$ It is reasonable, then, to assume that $*$ su was present as an oblique common noun preposition in Proto-South-Central Cordilleran and was inherited in Southern Cordilleran languages, spreading into nominative positions to form an $s$-initial [su 'common noun' : si 'proper noun'] analogical correspondence.

IVATAN (Yamada and Tsuchida I975:53)

(24) Pavohorən=mo=ako so payong=mo.

cause.borrow $=$ GEN.2S $=$ NOM.IS $\quad[$ PoBL umbrella $=$ GEN.2S $]$

'Lend me your (SG) umbrella.'

BAYOMBONG GADDANG (Yamada and Tsuchida I975:52)

(25) Mattaló:fư ino pá:ku so bá:to.

growing $\quad\left[\mathrm{P}_{\text {NOM }}\right.$ moss $]\left[\mathrm{P}_{\text {овL }}\right.$ stone $]$

'Moss is growing on the stone.'

YOGAD (Reid I977)

(26) Uminum yu tolay tu danum.

drink $\quad\left[\mathrm{P}_{\mathrm{NoM}}\right.$ man $]\left[\mathrm{P}_{\mathrm{OBL}}\right.$ water $]$

'The man is drinking water.'

In the Central Cordilleran languages, the Kalinga languages with *u-grade oblique prepositions provide evidence that *su was probably also an oblique preposition in

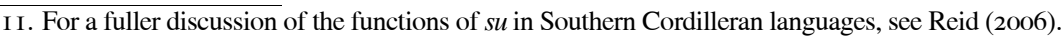

I2. Gaddang $s u$ shows an irregular reflex of $*$ su, because in this language, as in most of the Northern Cordilleran languages, ${ }^{*} \mathrm{~s}>t$ before back vowels (Tharp I974:72). However, Yogad, another of the Northern Cordilleran languages, has an appropriate reflex in YoG $t u$ 'oblique preposition'. Gaddang so introduces oblique phrases that specify common noun locations, and has probably developed by analogy with GAD si, which introduces oblique phrases that are not locations. 
Proto-Central Cordilleran, even though none of the daughter languages reflect the form unchanged. There is no evidence, though, from any of the South-Central Cordilleran languages, that there was a corresponding *du 'locative preposition', as is found in Ivatan, although there are some $d u$-initial place names in Northeastern Luzon, such as Dupaningan. Neither is there any evidence in South-Central Cordilleran languages for a *?u 'locative preposition' to which a nominal specifier *di could have been cliticized to produce *?ud. One must assume therefore that *?id was replaced by *?ud, because of vowel-grade harmony with $*^{\text {su. }}{ }^{13}$

Whether Proto-Central Cordilleran had both *si and *su prepositions with different distributions remains a problem for which there is no clear answer. Evidence that both forms existed is that while glottal-stop initial $u$-grade forms are found only in Kalinga languages, and glottal-stop initial $i$-grade forms are found only in Nuclear Cordilleran languages, *si is reflected as an oblique preposition in all branches of the family. Both forms are reflected as oblique prepositions with different syntactic distributions in the Northern Cordilleran language Gaddang, but in the Central Cordilleran languages their distribution is not syntactically distinct, but only geographical, implying that only one form (*su) is inherited and the other (*si) is a replacement, probably because of vowel-grade harmony.

Under the assumption, then, that Proto-Central Cordilleran only had *su 'common noun oblique preposition', the developments in Proto-Kalinga-Itneg and Proto-Nuclear Cordilleran are shown in table 5 . In this scenario, *su was replaced by *si as a result of vowel-grade harmony with the locative preposition *di, but not before Proto-Kalinga had replaced *?id with *?ud. Subsequently, *?us developed as a result of the analogical proportion [*=d : *2ud :: * $=\mathrm{s}:$ ?].

\section{TABLE 5. THE DEVELOPMENT OF PROTO-CENTRAL CORDILLERAN OBLIQUE AND LOCATIVE CASE-MARKING PREPOSITIONS}

\section{Proto-Central Cordilleran}

\begin{tabular}{|l|l|l|}
\hline & OBLIQUE & LOCATIVE \\
\hline $\mathrm{V}]$ & $*=\mathrm{s}$ & $*=\mathrm{d}$ \\
\hline $\mathrm{C}]$ & $*_{\mathrm{su}}$ & $*_{\mathrm{di}}$ *?id \\
\hline \multicolumn{3}{|c}{$\quad \boldsymbol{Y}$}
\end{tabular}

Proto-Kalinga-Itneg

\begin{tabular}{|l|l|l|}
\hline & OBLIQUE & LOCATIVE \\
\hline $\mathrm{C}]$ & $*=\mathrm{s}$ & $*=\mathrm{d}$ \\
\hline $\mathrm{C}]$ & $*$ si, $*$ ?us & $* \mathrm{di}, *$ ?ud \\
\hline
\end{tabular}

Proto-Nuclear Cordilleran

\begin{tabular}{|l|l|l|}
\hline & ObLIQUE & LOCATIVE \\
\hline $\mathrm{V}]$ & $*=\mathrm{s}$ & $*=\mathrm{d}$ \\
\hline $\mathrm{C}]$ & $*$ si, $*$ ?is & $* \mathrm{di}, *$ id \\
\hline
\end{tabular}

I3. It should be noted, however, that in some of the Central Cordilleran languages, the term for the locative question word 'where' appears to retain a frozen $u$-grade preposition. Some of these forms are: Balangao 'du:d, dok'kay; Bayyew Bontok du?ud; Talubin Bontok Pu?ud 'where'. Other languages in the group, however, have locative question words with either $i$ grade or $a$-grade forms, e.g., Guinaang Bontok 'Pintu, Amganad Ifugao Pi'dana, Guinaang Kalinga 'dinu; Bayninan Ifugao Pada:na 'where' (Reid I97I:I62). 
5. CONCLUSION. This paper has attempted to account for the different vowels that occur in the case-marking prepositions in a number of the languages of Northern Luzon. The fact that forms that otherwise appear to be cognate - because of their case-marking function and corresponding consonants - sometimes occur with an $a$-vowel, sometimes with an $i$-vowel, and sometimes with an $u$-vowel, suggests that a semantic feature is conditioning the quality of the vowel. Various linguists have, in fact, attempted to reconstruct the feature not only for the parent of the Philippine languages, but also for Proto-Austronesian itself. However, in the languages examined (the Central and Southern Cordilleran languages), no such feature has been described, and none can be determined. Furthermore, even closely related dialects of the same language sometimes exhibit different vowels. The discussion has focused primarily on the development of $i$-grade and $u$-grade oblique and locative forms. The development of oblique and locative $a$-grade forms probably followed the same analogical processes discussed for the other grades, although the details are not yet clearly understood. One thing is apparent, however: the $a$-grade forms are probably not reconstructible to Proto-Central Cordilleran, even though they are found in the two major branches of the family, Kalinga-Itneg and Nuclear Cordilleran, and an $a$-grade locative form also occurs in Pangasinan, a Southern Cordilleran language. Their development can only be accounted for as the result of independent local innovations in each of the languages and dialects in which they occur.

The explanation that has been provided in this paper is that analogical changes in at least the oblique and locative case forms of the languages involved have resulted in vowel agreements, such that those with an $i$ oblique preposition have also an $i$ locative preposition, those with an $a$ oblique preposition have also an $a$ locative preposition, and those with an $u$ oblique preposition have also an $u$ locative preposition.

In earlier work (Reid 2006), this was described as the result of a kind of long-distance vowel harmony, operating between the vowels of case-marking prepositions, occurring across phrase boundaries in a syntagmatic relationship, as, for example, between the markers of oblique noun phrases expressing the extended undergoer of a dyadic intransitive clause, and a following locative phrase expressing a proper noun location.

It has become apparent, however, that while obliquely marked phrases expressing a common noun location can occur in a syntagmatic relationship with locatively marked proper noun locations, oblique and locative markers of temporal phrases cannot cooccur in the same clause, as one marks future time, while the other marks past time. They are mutually exclusive and coexist only in a paradigmatic relationship. I now consider that the vowel changes that have been described in this paper are the result of analogical changes that occurred initially between the prepositional markers of such temporal phrases. They were then extended to include the marking of the other functions of oblique and locative phrases that were described in the early sections of this paper.

A contributing factor that underlies the variability in the vowel in these forms has also been identified and described. Typically, each of the languages in these groups shows alternation between a post-consonantal variant that consists of the initial (case-marking) consonant and the variable vowel, and a post-vocalic enclitic variant that consists only of the initial consonant of the full form. No study has been done of the number of instances involved, but it is a commonly recognized fact about these languages, that a fairly sub- 
stantial proportion of words end with vowels, so that while the consonant marking a given instance is always present, either in a full form or as an enclitic, the vowel is not, leaving children developing their own internal grammar the task of supplying the missing vowel. Copying a vowel that is present in a form marking a different case, but having the same or similar semantic features is apparently one of the options that a child has.

The variability in these forms creates a real problem for analysts attempting to reconstruct the forms that were present in one or another protolanguage. It is apparent that without careful, bottom-up reconstruction of the forms for each of the languages and language groups being examined, and explanations for the variability that is found, one runs the risk of mistaking widespread parallel development for inheritance.

\section{REFERENCES}

Allen, Janet. I978. Kankanaey adjuncts. Studies in Philippine Linguistics 2 ( I):82-I02. Benn, Keith. I982. The logical semantic and schematic structures of a Bontoc exhortation. Philippine Journal of Linguistics I3 ( I):23-60.

- I99I. Discourse approaches to cohesion: A study of the structure and unity of a Central Bontoc expository text. Studies in Philippine Linguistics, vol. 8 (2). Manila: Linguistic Society of the Philippines and Summer Institute of Linguistics.

Benton, Richard A. I97I. Pangasinan reference grammar. PALI Language Texts: Philippines. Honolulu: University of Hawai' $i$ Press.

Blust, Robert A. 2005. A note on the history of genitive marking in Austronesian languages. Oceanic Linguistics 44:215-22.

Brainard, Sherri. I99I. Theme, result, and contrast: A study in expository discourse in Upper Tanudan Kalinga. Series B-I06. Canberra: Pacific Linguistics.

- 2003. Karao Texts. Studies in Philippine Languages and Cultures, vol. I3. Manila: Linguistic Society of the Philippines and the Summer Institute of Linguistics.

Dixon, R. M. W. I994. Ergativity. Cambridge Studies in Linguistics 69. Cambridge: Cambridge University Press.

Dixon, R. M. W., and Alexandra Y. Aikhenvald. 2000. Introduction. In Changing valency: Case studies in transitivity, ed. by R. M. W. Dixon and Alexandra Y. Aikhenvald, I-29. Cambridge: Cambridge University Press.

Ferreirinho, Naomi. I993. Selected topics in the grammar of Limos Kalinga, the Philippines. Series B-I09. Canberra: Pacific Linguistics.

Gieser, C. Richard. I963. A grammatical sketch of Kalinga. Nasuli, Malaybalay, Bukidnon: Summer Institute of Linguistics.

- 1987. Guinaang Kalinga texts. Studies in Philippine Linguistics Supplementary Series: Philippine Texts, vol. 4. Manila: Linguistic Society of the Philippines and Summer Institute of Linguistics.

Grayden, Bruce. 1978. Southern Kalinga [language text]. In Folktale texts: Studies in Philippine Linguistics, vol. 2 (2), edited by Evan L. Antworth, I3-23. Manila: Linguistic Society of the Philippines and Summer Institute of Linguistics.

Hettick, Donna, and Carolyn Kent. I967. Uses of the particle di [in Northern Kankanay]. Ms. Library of the Summer Institute of Linguistics, Manila.

Lambrecht, Frans Hubert. I978. Ifugaw-English dictionary. Baguio City, Philippines: The Catholic Bishop Apostolic of the Mountain Province.

Newell, Leonard E. I993. Batad Ifugao dictionary with ethnographic notes. Linguistic Society of the Philippines Special Monograph Issue, no. 33. Manila: Linguistic Society of the Philippines. 
Reid, Lawrence A. I97I. Philippine minor languages: Word lists and phonologies. Oceanic Linguistics Special Publication No. 8. Honolulu: University of Hawai i Press.

- I973. Isinai field notes. Unpublished database file.

. I977. Yogad field notes. Unpublished database file.

. I978. Problems in the reconstruction of Proto-Philippine construction markers. In Second International Conference on Austronesian Linguistics: Proceedings, vol. I, edited by S. A. Wurm and Lois Carrington, 33-66. Canberra: Department of Linguistics, Research School of Pacific Studies, Australian National University.

- I979. Evidence for Proto-Philippine nominative marking. Philippine Journal of Linguistics Iо (I-2): I-20.

- I98 I. Proto-Austronesian genitive determiners. In Linguistics across continents: Studies in honor of Richard S. Pittman, edited by Andrew B. Gonzalez, FSC, and David Thomas, 97-I05. Manila: Summer Institute of Linguistics and Linguistic Society of the Philippines.

- 2002. Determiners, nouns or what? Problems in the analysis of some commonly occurring forms in Philippine languages. Oceanic Linguistics 4I:295-309.

- 2006. On reconstructing the morphosyntax of Proto-Northern Luzon. Paper presented at the Ioth International Conference on Austronesian Linguistics, Puerto Princesa, Palawan, Philippines, January I7-20.

Ross, Malcolm D. 2002. The history and transitivity of western Austronesian voice and voice-marking. In The history and typology of western Austronesian voice systems, ed. by Fay Wouk and Malcolm Ross, I7-62. Canberra: Pacific Linguistics.

Rubino, Carl Ralph Galvez. 2000. Ilocano dictionary and grammar. PALI Language Texts. Honolulu: University of Hawai'i Press.

Ruffolo, Roberta. 2005. Topics in the morpho-syntax of Ibaloy, Northern Philippines. $\mathrm{PhD}$ diss., Australian National University.

Scheerer, Otto. I92 I. Texts from Balbalasang-Ginaang. The Philippine Journal of Science I9 (2): $175-207$.

Shetler, Joanne. 1976. Notes on Balangao grammar. Language Data: Asian-Pacific Series, No. 9. Huntington Beach: Summer Institute of Linguistics.

Soberano, Rosa P. I980. The dialects of Marinduque Tagalog. Series B-69. Canberra: Pacific Linguistics.

Tharp, James A. I974. The Northern Cordilleran subgroup of Philippine languages. Working Papers in Linguistics, Department of Linguistics, University of Hawaii 6 (6):53-I I 4.

Walton, Janice. I975. Binongan Itneg sentences. Series B-32. Canberra: Pacific Linguistics.

Yamada, Yukihiro, and Shigeru Tsuchida. 1975. Philippine languages. Asian and African Grammatical Manual No. I 5b. Tokyo: Institute for the Study of Languages and Cultures of Asia and Africa, Tokyo University of Foreign Studies.

reid@hawaii.edu 